\title{
十如是の意味するもの
}

\section{瀧英 寛}

\section{1 十如是に対する従来の見解の問題点}

羅什訳『妙法蓮華経』方便品にのみ存在するいわゆる十如是は，諸法実相を示 す概念として重要視されてきた，そのために従来の十如是に対する理解は，後代 に展開した諸法実相論の影響を受けたものとなってしまっており，十如是の意味 を『法華経』に基づいて説明しているとは言い難い.

従来の見解は，十如是および諸法実相という訳語が羅什訳のみに存在するとい う事実を確認しておきながら，方便品の理解に置いては諸法実相という概念を極 めて重視しているが，それでは羅什訳以外の『法華経』は，経典としての核心部 分をまったく述べていないことになるから．従来の見解には，方便品の基本的な 理解において, 羅什訳のみに依拠した解釈が保持されているという問題点が存在 するのである。

諸法実相という訳語は，羅什が翻訳に関わった経論において見られ，それらの 経論においては, 確かに存在要素としての法が空であることを主張するアビダル マの文脈において使用されている。しかし『妙法蓮華経』における諸法実相が, 『大智度論』などにおいて使用されている諸法実相と同じ概念を指すと同定しても よいのか.そもそも『法華経』方便品において，アビダルマの議論が行なわれて いるのかという疑問が提示されるべきであろう。従って，諸法実相という訳語の 意味を方便品の主旨に基づいて確定する必要がある.

\section{2 方便品の主旨}

方便品前半部分は，「仏陀の智慧」〈buddha-jñāna〉と「方便」〈upāya-kauśalya〉 とに対する讃嘆から成立している。つまり如来によって説示された法に対する絶 対的な信頼を, 法を聞くものたちに要求しており, 決して三乗の教えを捨て去る ことを促すものではない.むしろ三乗の教えこそが, 仏陀の智慧から発生し, 偉 
大な方便力によって衆生に与えられた信じられるべき法として讃嘆されている. 諸法実相および十如是に相当する部分も, 如来のみがこれらの法を知っている点 を強調しているのみで, 特にアビダルマの議論を導入したり, 空という概念を主 張しょうとする意図などは認められない.

方便品後半部分の内容も踏まえるならば, 説かれて来たすべての法は, 仏陀の 智慧に基づく巧みな方便によって，それぞれの衆生に対応する形で示された法で あり，如来の最終的な意図としては，すべての法は衆生に仏陀の智慧を獲得させ るためだけに説かれている，如来が方便によって説示した法はすべて仏乗なので ある．というのが，方便品の主張であり，一乗という概念の基本的な意味であろ う。方便品という品題は, 如来の方便を偉大なものとして讃嘆する意味で名づけ られている。

それゆえに諸法実相という訳語も，方便品の主旨を踏まえるならば，この一乗 という概念を意味する言葉として理解されるべきである。この私見の妥当性を確 認するために，次に方便品における法の意味を考察する.

\section{3 方便品における法〈dharma〉}

法〈dharma〉という語が多義語であることは指摘するまでもないが, 『妙法蓮華 経』方便品における諸法実相という概念が, 従来のように理解されてしまう原因 は，この法という語にある．従来の見解は，方便品における諸法実相の諸法を， 『大智度論』などにおける諸法実相と等しい概念とみなして, 「もろもろの存在要 素」と理解している. しかし方便品における諸法実相の諸法は, 決してもろもろ の存在要素を意味していると見なすことはできない.

方便品においては，「諸如来が獲得した甚だ深い法」と「諸如来が方便によって 衆生に対して説示する法」とが主題となっており，それらの法を説示した如来の 意図するところが開示されている。この方便品の主旨を考慮するならば，「諸如来 が獲得した甚だ深い法」とは「仏陀の智慧」のことであり,「諸如来が方便によっ て衆生に説示する法」とは「仏陀の教説」のことであるから，アビダルマの文脈 において使用される存在要素としての法が, 諸法実相および十如是の部分におい て突然挿入される必然性はまったくない。「仏陀の智慧」と方便によって衆生に提 示される「仏陀の教え」としての法とが方便品に抏いて使用される法の基本的な 意味である，方便品においては，「仏陀の智慧」と「その智慧から派生した仏陀の 教え」とが同じく法という語によって表現されているのである。それゆえに，諸 
法実相の諸法とは，もろもろの仏陀の教えを意味する訳語として理解するべきで ある。

4 方便品に基づく諸法実相および十如是の意味

方便品の主旨に沿う限り, 羅什訳における「唯仏與仏乃能究盡諸法実相」とは, 「ただ仏と仏のみが，もろもろの教えの真実の様相，(すなわちもろもろの教えは究極 的な目的として仏陀の智慧を獲得するための乗り物であること）を十分に知り尽くすこ とができる」という意味である，そして「本末究竟等」とは，「(仏陀の教説は, ) 根 本的な教えと考えられる教説も，末端的な教えと考えられる教説も，(仏陀の智慧 を衆生に獲得させるために説かれたという如来の意図の下に拀いては，）等しく仏乗であ る」という意味を表現していると考えられる。また，「本末」の「本」が「仏陀の 智慧」を，「末」がその仏陀の智慧から派生した「仏陀の教え」を意味していると 考えることもでき，その場合は，「根本的な仏陀の智慧と（仏陀の智慧から見れば） 末端的な仏陀の教えとは究極的には等しいのである」という意味を表現している ことになる。「如是」は「この『法華経』において説き明かされるような」という 意味で使用されている.

問題は，「相・性・體・力・作・因・縁・果・報」という訳語であり，これらに 関しては, やはり『大智度論』の記述を参照して理解せざるを得ない. 従って, 諸法実相および十如是の訳出によって, 羅什は積極的に仏陀の教説としての法と 存在要素としての法との二重の意味の重ね合わせを意図していると判断せざるを 得ないのであるが，方便品の文脈のみから，そのような操作を行なうにはかなり の飛躍が必要である。それゆえに『妙法蓮華経』の訳出において，仏陀の教説と しての法と存在要素としての法とを積極的に結び付けるなんらかの媒介となる要 素が，『法華経』自体に存在すると想定すべきであろう。その契機となったと考え られるのが〔方便品の記述内容を表現を変えて説示する〕薬草喻品の記述である.

\section{5 薬草嗡品の記述}

薬草喻品においても，法という語は明らかに仏陀の教説を意味する法として使 用されているのであるが，たとえば，教えとしての法が最終的に空に帰着すると 述べられており, 方便品の主旨からは認められなかうた空の思想が持ち込まれて しまっている，それゆえに薬草喻品の記述を方便品の主張の単純な繰り返しと見 なすことはできない. 
そして薬草喻品には, 諸法を「もろもろの衆生存在」と解釈させる文脈が存在 する．つまり如来はあらゆる衆生の根性や機根を知っているという薬草喻品にお ける如来の説法能力の説明は, それぞれの衆生に対応した教えを如来のみが説く ことができるということを強調し，如来の説く教えとその説法対象である衆生と は，一対一で対忍していることを示しているので，方便品における如来のみがあ らゆる教えを知っており，説くことができるという主張と，薬草喻品における如 来のみがあらゆる衆生の状態を知り尽くして一相一味の法を説くことができると いう主張とは，同じ如来の説法能力を言い表わしていることになり，仏陀の教え としての法と衆生存在とは対応関係にあることになる. 従って, 薬草喻品の記述 は, 諸法実相および十如是として訳出できる内容を持ち合わせているのである. さらに薬草喻品の偈頌部分に扔いては, 力・縁・體・相・性・因 (縁) ・作・果と いう語が使用されているが，これらは十如是のうちの実に八つに対応する.

羅什はこの薬草喻品の記述を念頭に置き，ほぼ同一の主張を述べる方便品の記 述に対して, 補足説明するために薬草喻品における如来の説法能力の記述内容を 諸法実相および十如是として，先取りする形で訳出したと考えられるのである。 そして, 薬草喻品の記述内容を方便品の記述内容に重ね合わせる際に, 『大智度 論』の諸法実相という表現が使用されたと推察される.

十如是が薬草喻品の説示内容を要約したものであると見る場合, 諸法は「もろ もろの仏陀の教説」という意味よりも,「もろもろの衆生存在」という意味の方に 重点が置かれることになって，次のような意味を有していることになる.

「ただ仏のみがもろもろ教えとその教えに対応するもろもろの衆生存在との真実 の椂相を十分に知り尽くすことができる.（ただ仏のみが十分に知り尽くすことができ ると）言うところの，教えに対応するもろもろの衆生が，この『法華経』におい て説き明かされるような様相・性分を持ち，仏陀の教説を聞くことによる力を得 て, 作仏し，この『法華経』に掞いて解き明かされるような因縁を持ち，この『法 華経』に説き明かされるように（仏の説く教えによって）全員が等しく成仏する（こ とをただ仏のみが知っている).」(紙数の都合上, 注記・参考文献等は略)

〈キーワード〉 䲨摩羅什, 諸法実相, 十如是 